\title{
DOES PERFORMANCE OF SPEED-ACCURACY MOVEMENTS DEPEND ON GENDER AND THE LEFT OR THE RIGHT HAND?
}

\author{
Kristina Motiejūnaitė, Dalia Mickevičienė, Albertas Skurvydas, Diana Karanauskienė, \\ Mantas Mickevičius \\ Lithuanian Academy of Physical Education, Kaunas, Lithuania
}

Kristina Motiejūnaitè. PhD student in Social Sciences, Asistant at the Department of Health and Physical Activity, Lithuanian Academy of Physical Education. Research interests - motor learning.

\begin{abstract}
The aim of the study was to establish the differences in men and women's performance of speed-accuracy movements with their left $(\mathrm{LH})$ and right $(\mathrm{RH})$ hands. The research participants were 24 healthy right-handed subjects: 12 males (aged $20.8 \pm 1.1$ years) and 12 females (aged $21.4 \pm 1.0$ years).

The research was carried out in the Laboratory of Human Motor Control at the Lithuanian Academy of Physical Education (LAPE) applying the analyzer of dynamic parameters of human leg and arm movement (DPA-1; Patent No. 5251; 200508 25), which is used for the qualitative estimation of the dynamic parameters of one arm and leg target movement, two arms and legs coordinated and independent target movements, when the resistance power and target are coded with different programmable parameters.

The task was performed with the right and then with the left hand (50 repetitions with each hand). The subjects had two tasks: a) to react as quickly as possible (simple task); b) to react as quickly as possible and to hit the target on a computer screen quickly and accurately (complicated task). We registered the maximal and mean movement speed, reaction time, movement trajectory and intraindividual variability of the right and the left hands.

Conclusions. There was no significant difference in accuracy between female and male subjects, thought female subjects performed speed-accuracy task more slowly than men. Both males and females performed the speed-accuracy task with their right hand faster and more accurately than with their left hand. Performing movements with different hands the indices of reaction time did not differ significantly. Both males and females performed movements with their right and left hands with the same intraindividual variability.
\end{abstract}

Keywords: movement control, reaction time, speed-accuracy task, right and left hand, gender.

\section{INTRODUCTION}

$\mathrm{T}$ There is much research analyzing reaction time, movement speed and accuracy and their dependence on gender (Botwinick, Thompson, 1966; Grabowska et al. 1994, 1999; Nicholson, Kimura, 1996; Dane, Erzurumluoglu, 2003; Barral, Debû, 2004; Der, Deary, 2006;) and the right or the left hand (Grabowska et al., 1994; Bryden, 2002; Dane, Erzurumluoglu, 2003). It is accepted that the female human brain is less lateralized than that of males (Grabowska et al.,
1994). Despite this and other research it is not clear yet what the main differences in the performance of various movements of males and females with their right and their left hands are. The main problem of clear generalization of motor control differences between males and females, as well as their right and left hands, lies in the fact that motor control also depends of the degree of movement complexity, the type of movement, the subjects' hand preference and their athletic fitness and age. 
It has been established that males have faster reaction times than females, and female disadvantage is not reduced by practice (Der, Deary, 2006). However, it has been determined that performing speed - accuracy movements women performed them more slowly and accurately than men (Adam, 1999; Dane, Erzurumluoglu, 2003; Barral, Debû, 2004). Besides, women accomplished the Moberg Pick-Up Test (i.e. test for assessing hand dexterity) faster than men, and task performance with the dominant hand was faster than with the nondominant hand (Amirjani et al., 2007). However, male subjects drew circles at significantly higher speeds than female subjects (Rueckriegel et al., 2008). Summing up, we maintain that so far it is not clear who perform movements more accurately and faster - men or women. Besides, we have not found homologous conclusions explaining how lateralization depends on gender.

The left hemisphere is regarded as the verbal and logical brain, and the right hemisphere is thought to govern creativity and spatial relations, among other things. Also, the right hemisphere controls the left hand, and the left hemisphere controls the right hand. Right-handers exhibit a left hand advantage in response preparation when pointing to targets. This has made researchers think that the left hand should be faster at reaction times involving spatial relationships (such as pointing at a target). More precisely, the left hand reaction time (RT) advantage has recently been supposed to reflect specifically the right hemisphere superiority for movement planning. The results of Boulinquez and S. Bartélémy (2000) and S. Bartélémy and P. Boulinquez $(2001,2002)$ supported this idea.

Is has been established that the intraindividual variability of reaction time is a significant criterion of cognitive performance capacity (Hultsch et al., 2002; Bunce et al., 2008; McIntosh et al. 2008; Ullén et al., 2008). We have not come across any studies analyzing the difference in intraindividual variability of reaction time, movement speed as well as accuracy during speed-accuracy task between male and female subjects, and between their left and right hands.

We aimed to check the following assumptions: a) whether the left hand reacts faster while performing a speed - accuracy movement than the right hand (Boulinquez, Bartélémy, 2000); b) whether women react slower but more accurately than men while performing speed - accuracy movements (Barral, Debu, 2004); c) whether lateralization in women is less expressed than in men (Grabowska et al., 1994); d) and whether right-handed persons' intraindividual variability of reaction time, as well as kinematic characteristics of movement of the left hand are higher than those of the left hand.

\section{RESEARCH METHODS}

Subjects. 12 healthy males aged $20.8 \pm 1.1$ years, body mass $-77.0 \pm 9.2 \mathrm{~kg}$, height $-182.33 \pm$ $6.65 \mathrm{~cm}$; and 12 healthy females aged $21.4 \pm$ 1.2 years, body mass $-61.1 \pm 6.2 \mathrm{~kg}$, height $170.3 \pm 4.7 \mathrm{~cm}$. participated in the research. All the subjects were right-handed. The assessment and analysis of handedness was performed by the Edinburgh Inventory (Oldfield, 1971). They were informed about the course of the study. The subjects were physically active, but did not take part in any formal physical exercise or sport program.

Research protocol. The research was carried out in the Laboratory of Human Motor Control at the Lithuanian Academy of Physical Education (LAPE) applying the analyzer of dynamic parameters of human leg and arm motion (DPA-1; Patent No. $5251 ; 20050825$ ), which is used for the qualitative estimation of the dynamic parameters of one arm and leg target movement, two arms and legs coordinated and independent target movements, when the resistance power and target are coded with different programmable geometrical, chromatic and temporarily set parameters.

During the research the subjects were seated in a special chair at the table with a DPA-1 fastened to it. The subject's back was straight and leant at the backrest; both arms were bent $90^{\circ}$ at the elbow joint so that the upper arms were nestled against the sides, and the forearms rested on DPA1 support panel. The position of DPA-1 chair was regulated so that the subject could sit comfortably and take a standard position. The distance between the computer screen and the subject's eyes was approximately $70 \mathrm{~cm}$. One hand of the participant gripped the handle of a joystick. Participants were instructed to focus on the cross in the centre of the screen, and push the joystick with their hand a) as quickly as possible (first task) and b) quickly and accurately (second task) in response to the visual signal (appearance of a red circle on the screen).

On the screen the height of the task performance field was $200 \mathrm{~mm}$, and the width $-270 \mathrm{~mm}$. In accordance with the task prepared in advance a target - a red circle $3.5 \mathrm{~mm}$ in diameter - appeared in the middle of the field of task performance (height 
$170 \mathrm{~mm}$, width $135 \mathrm{~mm})$. The distance between the start zone and the target center was $160 \mathrm{~mm}$. The trajectory of the hand movement was identically repeated on the computer screen. During each task the subject set the handle symbol of $3.5 \mathrm{~mm}$ in diameter to the start zone - the center of a green circle the diameter of which was $10 \mathrm{~mm}$. The start zone was in the middle of the task performance field on the screen.

The subject had to react to the target on the computer screen and the accompanying sound signal as quickly as possible and to push the handle of the device so that the circle of the handle symbol reached the target as quickly as possible and in the most accurate trajectory, and then remained in it. The program intermittently (every $1-3 \mathrm{~s}$ ) generated a sound signal and a target in a certain and the same place on the computer screen, and the subject had to react to it pushing the handle of the device. The measurement cycle was completed after the handle symbol hit the target. The target appeared on the computer screen in the same place. The end point of the movement was fixed when the centre of the handle symbol stopped in the target circle and remained there no shorter than $0.02 \mathrm{~s}$. After the task was explained the subjects were allowed to perform three trials, and their results were not recorded. The first and the second tasks included 50 repetitions and were performed with one hand without stopping, then after a 2 min break the same tasks were performed with the other hand. The subject performed the task with the right hand using the right handle of the device, and while they performed the task with the left hand, the left handle of the device was used. After each repetition the subjects could see their result on the computer screen. They were encouraged to perform the task as quickly and accurately as possible.

During the first task we registered only reaction time (RT), while during the second task we registered the maximal (Vmax) and the mean movement speed (Vmean), RT, movement path (S) of the right and the left hands. Besides, we calculated intraindividual variability of these variables.

Statistics. The one-way analysis of variance (ANOVA) for repeated measurements was used to determine the effect of gender (female vs. male) and lateralization (right vs. left hand) on different measurements. If significant effects were found, post hoc testing was performed applying paired t-tests with a Bonferroni correction for multiple comparisons. Descriptive data were presented as means $\pm \mathrm{SD}$. The level of significance was set at 0.05 . Based on alpha level of 0.05 , sample size $(n=12)$ standard deviations and average level of variables statistical power (SP) were calculated for all mechanical indicators. In order to evaluate the relationship between right and left hand in different variables Pearson's coefficient of correlation was calculated.

\section{RESULTS}

There was no significant $(\mathrm{p}>0.05)$ difference in RTs (simple reaction time) between male and female subjects, as well as between right hand $(\mathrm{RH})$ and left hand (LH) (Figure 1). However, RTc was significantly greater and Va was significantly less $(\mathrm{p}<0.05)$ in women than in men, both in their right and left hands (Figure 2, 3), while there was no significant $(\mathrm{p}<0.05)$ difference in $\mathrm{Vm}$ between male and female subjects in both $\mathrm{RH}$ and LH (Figure 4). We did not find any difference in RTc as well as Vm between hands (Figure 2, 4), while Va was significantly $(\mathrm{p}<0.01)$ greater and S significantly $(p<0.01)$ shorter in the right hand than in the left for both male and female subjects (Figure 3, 5).

There was no significant difference in intraindividual variability of RTS, RTc, Va,

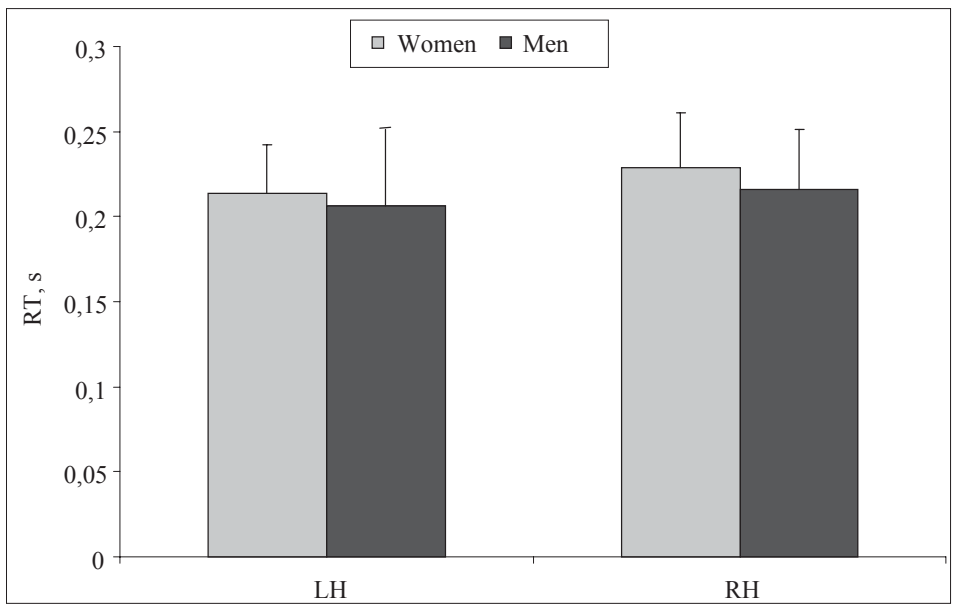

Figure 1. The mean value of simple reaction time (RTs) of males and females performing task with 50 repetitions
Note. \#-p $<0.05$ comparing the results of the right and the left hands of males and females. 
Figure 2. The mean values of the reaction time (s) of males and females performing a task with 50 repetitions

Note. \# - p $<0.001$ comparing the results of the right and the left hands of males and females.

Fig. 3. The mean values of movement average speed $(\mathrm{mm} / \mathrm{s})$ of males and females performing a task with 50 repetitions

Fig. 4. The mean values of movement maximal speed $(\mathrm{mm} / \mathrm{s})$ of males and females performing a task with 50 repetitions

Note. * - p $<0.05$ comparing the results of the right and the left hands of males and females.

Fig. 5. The mean values of the movement trajectory (mm) of males and females performing a task with 50 repetitions
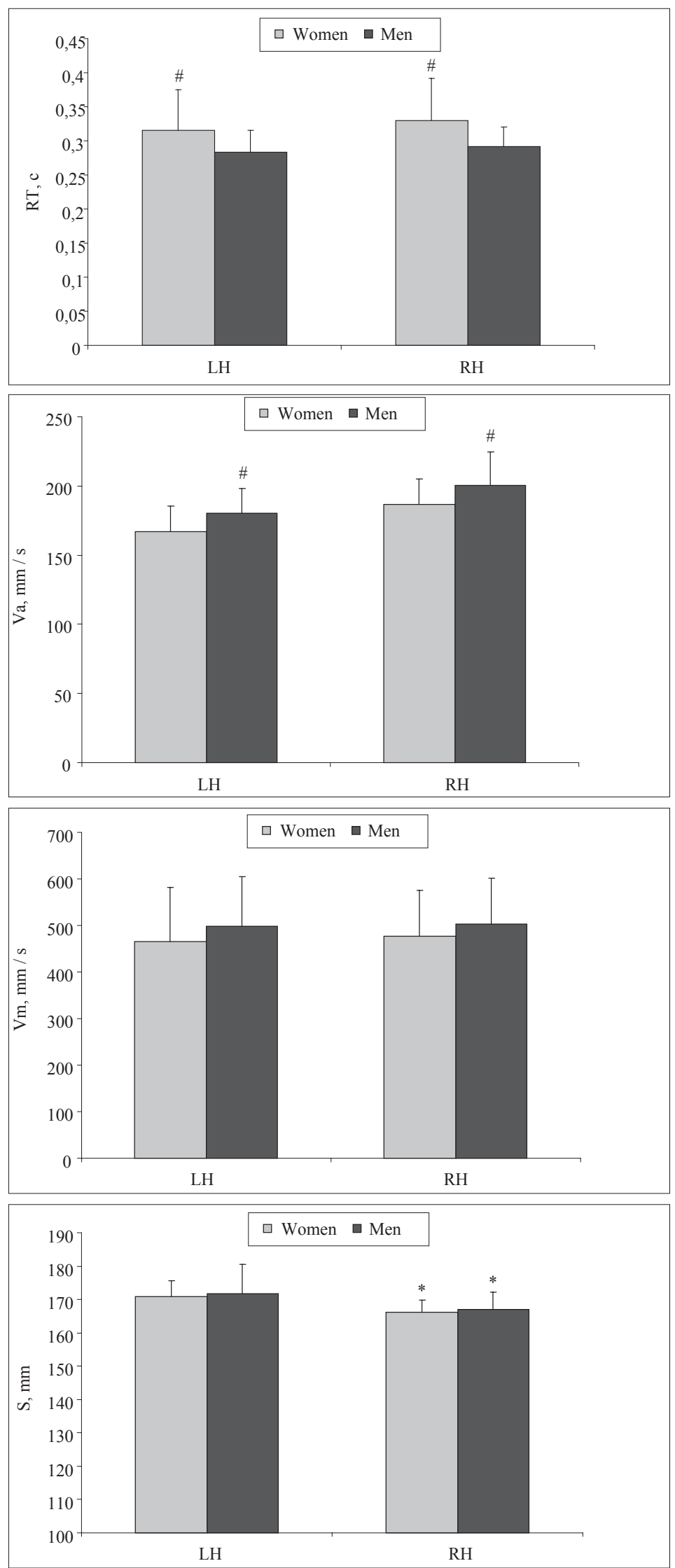

$\mathrm{Vm}$ and $\mathrm{S}$ between male and female subjects as well as between RH and LH except the fact that intraindividual variability of $\mathrm{S}$ both in male and female was significantly less in $\mathrm{RH}$ than in $\mathrm{LH}$
(Table). Besides, the intraindividual variability of Va was significantly $(p<0.001)$ greater than intraindividual variability of $\mathrm{Vm}, \mathrm{RTs}$, TRc and S both in RH and LF as well in males and females. 


\begin{tabular}{|l|c|c|c|c|c|}
\hline Parameters & $\mathbf{R T}, \mathbf{s}$ & $\mathbf{R T c}$ & $\mathbf{V}_{\mathbf{m}}$ & $\mathbf{V}_{\mathbf{a}}$ & $\mathbf{S}$ \\
\hline Men LH & $17.2 \pm 5.9$ & $16.4 \pm 3.8$ & $12.7 \pm 3.9$ & $28.50 \pm 5.95$ & $5.7 \pm 2.3$ \\
\hline Men RH & $17.9 \pm 6.2$ & $16.7 \pm 4.4$ & $11.1 \pm 4.3$ & $27.31 \pm 4.98$ & $4.2 \pm 1.6^{*}$ \\
\hline Women LH & $20.2 \pm 6.9$ & $19.6 \pm 9.9$ & $11.7 \pm 2.4$ & $27.22 \pm 5.42$ & $5.5 \pm 1.9$ \\
\hline Women RH & $21.1 \pm 5.4$ & $18.5 \pm 4.3$ & $10.1 \pm 2.6$ & $26.45 \pm 5.08$ & $4.2 \pm 2.5^{*}$ \\
\hline
\end{tabular}

Table. Intraindividual coefficients of variance of male and female right and left hand registered parameters

\section{DISCUSSION}

The data of our research did not confirm our hypotheses. We found that a) there was no significant difference in reaction time both in the simple as well as in the complex task between $\mathrm{LH}$ and $\mathrm{RH}$; b) there was no significant difference in accuracy between female and male subjects, thought female subjects performed speed-accuracy task more slowly than men; c) there was no significant difference in hand lateralization between female and male subjects; d) right-handed person's intraindividual variability of reaction time, as well as kinematic characteristics of movement of the left hand did not differ from those of the right hand.

Contrary to us, P. Boulinquez and S. Bartélémy, (2000) established that right-handed people react faster with their left hand when performing accuracy movements. Our findings contradict to the data obtained by J. Barral and B. Debu, (2004). It was them who found that while men were faster than women at aiming at a target, women were more accurate. Our findings do not confirm this fact as we have not established statistically significant differences between the trajectory of movement performance of males and females, however the movement trajectory was statistically significantly different between the right and the left hand for all the subjects - right-handers performed the movements with their right hand faster and more accurately (Figure 3, 5). However, our research results showed that female subjects performed speed-accuracy task more slowly than men (Figure 3). Agreeably to Grabowska et al. (1994) hypothesis, we expected greater differences in RTs,
$\mathrm{Va}, \mathrm{Vm}$ and $\mathrm{S}$ between the right and the left hand for men compared to women. But our hypothesis was not confirmed that male lateralization was more expressed than that of females. (Figure 1, 2, 3, 4).

It has been established that speed and accuracy of the non-dominant hand decreases more than those of the dominant hand when the complexity of movement performance increases (Lewis et al., 2002). We expected that right-handed persons would have difficulties in controlling movements with their left hand, and thus we thought that variability of parameters of left hand movements should be higher than that of the right hand. More especially that, e. g. the intraindividual variability of reaction time is a significant criterion of cognitive performance capacity (Hultsch et al., 2002; Bunce et al., 2008; McIntosh et al., 2008; Ullén et al., 2008). However, this idea was not confirmed by our findings, we did not find any differences in the variability of parameters of movement performance with the right and the left hands (Table).

\section{CONCLUSIONS}

There was no significant difference in accuracy between female and male subjects, thought female subjects performed speed-accuracy task more slowly than men. Both males and females performed the speed-accuracy task with their right hand faster and more accurately than with their left hand. Performing movements with different hands the indices of reaction time did not differ significantly. Both males and females performed movements with their right and left hands with the same intraindividual variability.

\section{REFERENCES}

Adam, J., Paas, F., Buekers, M. et al. (1999). Gender differences in choice reaction time: Evidence for differential strategies. Ergonomics, 42, 327-335.

Amirjani, N., Ashworth, N. L., Gordon, T., Edwards, D. C., Chan, K. M. (2007). Normative values and the effects of age, gender, and handedness on the Moberg Pick-Up Test. Muscle Nerve, 35 (6),788-92.

Barral, J., Debu, B. (2004). Aiming in adults: Sex and laterality effects. Laterality: Assymmetries of Body, Brain and Cognition, 9 (3), 299-312.

Barthélémy, S., Boulinguez, P. (2001). Manual reaction time asymmetries in human subjects: The role of movement planning and attention. Neuroscience Letters, 315 (1), $41-44$.

Barthélémy, S., Boulinguez, P. (2002). Orienting visuospatial attention generates manual reaction time asymmetries in target detection and pointing. Behavioral Brain Research, 133 (1), 109-116.

Botwinick, J., Thompson, L. W. (1966). Components of reaction time in relation to age and sex. Journal of Genetic Psychology, 108, 175-183.

Boulinguez, P., Barthélémy, S. (2000). Influence of the movement parameter to be controlled on manual RT asymmetries in right-handers. Brain and Cognition, 44 (3), 


\section{$653-661$}

Bryden, P. (2002). Pushing the limits of task difficulty for the right and left hands in manual aiming. Brain and Cognition, 48 (2-3), 287-291.

Bunce, D., Tzur, M., Ramchurn, A., Gain, F., Bond, F. W. (2008). Mental health and cognitive function in adults aged 18 to 92 years. Journal of Gerontology: Psychological Sciences, Series B, 63, 67-74

Dane, S., Erzurumluoglu, A. (2003). Sex and handedness differences in eye-hand visual reaction times in handball players. International Journal of Neuroscience, 113 (7), 923-929.

Der, G., Deary, I. J. (2006). Age and sex differences in reaction time in adulthood: Results from the United Kingdom health and lifestyle survey. Psychology and Aging, 21 (1), 62-73.

Grabowska, A., Herman, A., Nowicka, A., Szatkowska, I., Szelag, E. (1994). Individual differences in the functional asymmetry of the human brain. Acta Neurobiologian Experimentalis (Wars), 54 (2),155-162.

Hultsch, D. F., MacDonald, S. W., Dixon, R. A. (2002). Variability in reaction time performance of younger and older adults. Journal of Gerontology: Psychological Sciences, Series B, 57 (2), 101-115.
Lewis, S. R., Duff, S. V., Gordon, A. M. (2002). Manual asymmetry during object release under varying task constraints. The American Journal of Occupational Therapy, 56 (4), 391-401.

McIntosh, A. R., Kovacevic, N., Itier, R. J. (2008). Increased brain signal variability accompanies lower behavioral variability in development. PLoS Computational Biology, 4, e1000106

Nicholson, K. G., Kimura, D. (1996). Sex differences for speech and manual skill. Perceptual and Motor Skills, 82 (1), 3-13.

Oldfield, R. C. (1971). The assessment and analysis of handedness: The Edinburgh Inventory. Neuropsychologia, 9, 97-113.

Rueckriegel, S. M., Blankenburg, F., Burghardt, R. et al. (2008). Influence of age and movement complexity on kinematic hand mavement parameters in childhood and adolescence. International Journal of Developmental Neuroscence, Nov, 26 (7), 655-663.

Ullén, F., Forsman, L., Blom, O., Karabanov, A., Madison, G. (2008). Intelligence and variability in a simple timing task share neural substrates in the prefrontal white matter. Journal of Neuroscence, 28, 4238-4243.

\title{
AR GREITŲ IR TIKSLIŲ JUDESIŲ ATLIKIMAS PRIKLAUSO NUO LYTIES IR RANKOS?
}

\author{
Kristina Motiejūnaitė, Dalia Mickevičienė, Albertas Skurvydas, Diana Karanauskienė, \\ Mantas Mickevičius \\ Lietuvos kūno kultūros akademija, Kaunas, Lietuva
}

\section{SANTRAUKA}

Tyrimo tikslas - nustatyti, kaip skiriasi vyrų ir moteru greitų bei tikslių judesių atlikimas kaire ir dešine ranka atliekant sudètingą užduotị. Buvo tiriami 24 sveiki dešiniarankiai — 12 vyrų (amžius 20,8 $\pm 1,1 \mathrm{~m}$.) ir 12 moterų (amžius 21,4 $\pm 1,0 \mathrm{~m}$.).

Tyrimas atliktas Lietuvos kūno kultūros akademijos (LKKA) Judesių valdymo laboratorijoje naudojant žmogaus rankų ir kojų judesių dinaminių rodiklių analizatorių (DPA-1) (patento Nr. 5251; 2005 08 25), skirtą kokybiniams vienos rankos, kojos tikslinio judesio, abiejų rankų, kojų koordinuotų ar nepriklausomų tikslinių judesių dinaminiams rodikliams matuoti.

Užduotis buvo atliekama dešine, paskui kaire ranka (50 kartojimų kiekviena ranka). Tiriamasis turèjo atlikti dvi užduotis: a) kiek imanoma greičiau sureaguoti (paprasta užduotis); b) kiek i̇manoma greičiau sureaguoti ir kuo tiksliau pataikyti i taikini, esanti kompiuterio ekrane (sudėtinga užduotis). Buvo registruojamas kiekvienos rankos vidutinis ir maksimalusis judesio greitis, reakcijos laikas, judesio atlikimo kelias, skaičiuotas registruotu rodiklių kintamumas.

Judesio tikslumas statistiškai reikšmingai nesiskyrẻ tarp vyrų ir moterų, tačiau moterys greitumo ir tikslumo užduotị (sudètingą) atliko lečiau nei vyrai. Ir vyrai, ir moterys greitumo bei tikslumo užduoti dešine ranka atliko greičiau ir tiksliau nei kaire. Atliekant judesius skirtingomis rankomis, reakcijos laikas skyrèsi statistiškai nereikšmingai. Vyrų ir moteru judesiai, atliekami dešine ir kaire ranka, buvo vienodai kaitūs. lytis.

Raktažodžiai: judesių valdymas, reakcijos laikas, greitumo ir tikslumo užduotis, dešinė ir kairè ranka,

Gauta 2010 m. kovo 3 d.

Received on March 3, 2010

Priimta 2010 m. gegužès $31 \mathrm{~d}$.

Accepted on May 31, 2010
Kristina Motiejūnaitè

Lithuanian Academy of Physical Education

(Lietuvos kūno kultūros akademija)

Sporto str. 6, LT-44221 Kaunas

Lithuania (Lietuva)

Tel +370 37302645

E-mail kmotiejunaite@yahoo.com 